\title{
Oleate Uptake by Cardiac Myocytes Is Carrier Mediated and Involves a 40-kD Plasma Membrane Fatty Acid Binding Protein Similar to That in Liver, Adipose Tissue, and Gut
}

Dario Sorrentino, Decherd Stump, Barry J. Potter, Richard B. Robinson, Roy White, Chi-Li Kiang, and Paul D. Berk Departments of Medicine (Polly Annenberg Levee Hematology Center and Hepatic Research Group) and Biochemistry, Mount Sinai School of Medicine of the City University of New York, New York 10029; Department of Pharmacology, Columbia University College of Physicians and Surgeons, New York 10032; and Department of Physiology, Albert Einstein Medical College, Bronx, New York 10461

\begin{abstract}
Uptake of $\left.{ }^{3} \mathbf{H}\right]$ leate by canine or rat cardiac myocytes is saturable, displays the countertransport phenomenon, and is inhibited by phloretin and trypsin. Cardiac myocytes contain a basic (pI 9.1) 40-kD plasma membrane fatty acid binding protein (FABP $_{\text {PM }}$ ) analogous to those recently isolated from liver, adipose tissue, and gut, unrelated to the 12-14-kD cytosolic FABP in these same tissues. An antibody to rat liver FABP selectively inhibits specific uptake of $\left[{ }^{3} \mathrm{H}\right]$ oleate by rat heart myocytes at $37^{\circ} \mathrm{C}$, but has no influence on nonspecific $\left[{ }^{3} \mathrm{H}\right]-$ oleate uptake at $4^{\circ} \mathrm{C}$ or on specific uptake of $\left[{ }^{3} \mathrm{H}\right]$ glucose. Uptake of long-chain free fatty acids by cardiac muscle cells, liver, and adipose tissue and absorption by gut epithelial cells is a facilitated process mediated by identical or closely related plasma membrane FABPs.
\end{abstract}

\section{Introduction}

Even though the heart capillary endothelium represents a barrier to free fatty acid (FFA) extraction by the myocyte $(1,2)$, uptake rates in vivo are substantial (1). Indeed, FFA represent the most important substrate for myocardial energy metabolism under basal conditions. With regard to the mechanism of FFA uptake, some have suggested that the transfer of FFA from plasma into the cell is carrier mediated $(3,4)$ whereas others argue that the process is equilibrative and that the kinetics observed reflect intracellular metabolism rather than membrane transport $(5,6)$. However, earlier studies $(5,6)$ of cardiac FFA uptake employed $\mathrm{Ca}^{2+}$-intolerant myocytes in which sarcolemma permeability is altered (7). They also failed to consider the contribution of rapid efflux to the shape of the FFA uptake curve. Hence, the nature of the uptake process in cardiac myocytes remains uncertain. By contrast, studies from several laboratories, including our own, have documented that FFA uptake by hepatocytes $(8,9)$ and adipocytes $(10-12)$ is unequivocally carrier mediated, and that a $40-\mathrm{kD}$ plasma membrane fatty acid binding protein $\left(\mathrm{FABP}_{\mathrm{PM}}\right)^{1}$ isolated from

Address reprint requests to Dr. Sorrentino, Department of Medicine, Box 1079, Mount Sinai School of Medicine, One Gustave L. Levy Place, New York, NY 10029.

Received for publication 14 August 1987 and in revised form 11 April 1988.

1. Abbreviations used in this paper: $\mathrm{CCCP}$, carbonyl cyanide $m$-chlorophenylhydrazone; FABP, fatty acid binding protein; $F_{A B P}$, plasma membrane FABP.

J. Clin. Invest.

(c) The American Society for Clinical Investigation, Inc.

0021-9738/88/08/0928/08 \$2.00

Volume 82, September 1988, 928-935 these tissues and from the gut (12-14) plays an essential role in fatty acid uptake $(8,9,12,15)$. The aims of the present study were, therefore $(a)$ to study the uptake of a representative FFA, $\left[{ }^{3} \mathrm{H}\right]$ oleate, by well-characterized, $\mathrm{Ca}^{2+}$-tolerant dog and rat cardiomyocyte preparations using a technique that allowed accurate determination of initial influx rates; $(b)$ to isolate and characterize a putative cardiac myocyte $\mathrm{FABP}_{\mathrm{PM}}$; and $(c)$ to examine its role in FFA uptake by means of antibody inhibition studies. A preliminary report of our findings has appeared in abstract form (16).

\section{Methods}

Materials. D-[1- $\left.{ }^{3} \mathrm{H}(N)\right]$ glucose $(15.5 \mathrm{Ci} / \mathrm{mmol})$ and $9,10-\left[{ }^{3} \mathrm{H}\right]$ oleic acid (2.6 Ci/mmol) came from New England Nuclear (Boston, MA); nonradioactive oleate, carbonyl cyanide $m$-chlorophenylhydrazone (CCCP), phloretin, KCN, and ouabain from Sigma Chemical Co. (St. Louis, MO); bovine serum albumin (BSA, fatty acid free) from Boehringer Mannheim (Indianapolis, IN); and trypsin from ICN (Cleveland, $\mathrm{OH})$.

Isolation of myocytes. Cardiac myocytes were isolated from dogs (1-2-yr-old beagles) or rats (55-60-d-old Sprague Dawley) by collagenase perfusion in the presence of $\mathrm{CaCl}_{2}(7,17)$, and resuspended in Hepes-Ringer containing 3\% BSA until use. Approximately 85-90\% of all cells excluded trypan blue. Of these, up to $80 \%$ retained the rod shape. It has been previously shown that, with respect to specific physiologically relevant parameters, these myocytes are ultrastructurally, pharmacologically, and electrophysiologically indistinguishable from intact heart $(7,17)$. Data presented below were obtained with canine cardiac myocytes except where the use of rat heart myocytes is specifcally indicated.

Incubation and uptake procedures. For the uptake studies myocytes were washed three times and resuspended $\left(\sim 1 \times 10^{6} / \mathrm{ml}\right)$ in Hanks' buffer containing $10 \mathrm{mM}$ Hepes $(\mathrm{HH}), \mathrm{pH} 7.4$, gassed for $5 \mathrm{~min}$ with 95\% $\mathrm{O}_{2}, 5 \% \mathrm{CO}_{2}, 9,10-\left[{ }^{3} \mathrm{H}\right]$ oleic acid and measured amounts of nonradioactive oleate and BSA were also dissolved in $\mathrm{HH}$ at oleate/ BSA molar ratios from 0.5:1 to 6:1, producing unbound oleate concentrations of 0.04-21.9 $\mu \mathrm{M}(18,19)$. Except where specified, final BSA concentration was $208 \mu \mathrm{M}$. At zero time $500 \mu$ l of the appropriate oleate solution was added to $100 \mu \mathrm{l}$ of cell suspension in a $15-\mathrm{ml}$ polystyrene tube (Sarstedt, Inc., Princeton, NJ). At specific intervals thereafter uptake was blocked with $5 \mathrm{ml}$ of an ice-cold $200 \mu \mathrm{M}$ phloretin/0.1\% BSA stop solution in $\mathrm{HH}$; the mixture was immediately filtered and the filters counted by liquid scintillation spectrometry $(8,9)$. Cell-associated radioactivity at zero time was determined by adding stop solution to the cells before adding the $\left[{ }^{3} \mathrm{H}\right]$ oleate-BSA. Nonspecific oleate adsorption to the filter was routinely measured and subtracted from experimental values, of which it represented $<15 \%$. In all instances, the cumulative curve of cell associated radioactivity vs. time was linear, with its maximal positive slope, for at least the first $40 \mathrm{~s}$ after addition of $\left[{ }^{3} \mathrm{H}\right]$ oleate. The initial oleate uptake velocity was estimated as the slope of this initial, linear portion of the cumulative radioactivity curves, as previously described $(8,9,12)$.

Where indicated, cells were preincubated for $15 \mathrm{~min}$ at $4^{\circ} \mathrm{C}$ (phloretin) and $37^{\circ} \mathrm{C}(\mathrm{KCN}, \mathrm{CCCP}$, ouabain, trypsin) under condi- 
tions previously described $(8,9)$ before determining $\left[{ }^{3} \mathrm{H}\right]$ oleate uptake. To evaluate whether $\mathrm{Na}^{+}$substitution affects the uptake process, myocytes were resuspended in $\mathrm{HH}$ buffer in which $\mathrm{Na}^{+}$had been isoosmotically replaced by $\mathrm{K}^{+}, \mathrm{Li}^{+}$, choline, or sucrose; the experiment was performed immediately thereafter. The absence of $\mathrm{Na}^{+}$or the presence of the inhibitors listed above did not affect cell viability as assessed by trypan blue exclusion and the average number of myocytes which retained the rod shape. These variables were assessed on a separate aliquot of identically treated cells, during the uptake study.

Isolation and characterization of a sarcolemma protein with high affinity for fatty acids. Isolated canine cardiac myocytes $\left(\sim 50 \times 10^{6}\right.$ cells, $1.5 \mathrm{mg}$ of cell protein $/ 10^{6}$ cells $)$ were resuspended $(1: 10 \mathrm{vol} / \mathrm{vol})$ in $1 \mathrm{mM} \mathrm{NaHCO}, 1 \mathrm{mM} \mathrm{CaCl}_{2}, \mathrm{pH} 7.5$ and sonicated three times $(10$ $s$ each in ice). From resulting cell fragments a crude plasma membrane preparation ( $4 \mu \mathrm{g}$ of membrane protein $/ \mathrm{mg}$ cell protein) was obtained by differential centrifugation. Membrane proteins were extracted by gentle sonication for $30 \mathrm{~min}$ at $0^{\circ} \mathrm{C}$ in a $2 \mathrm{M} \mathrm{NaCl}, 0.05 \mathrm{M}$ phosphate

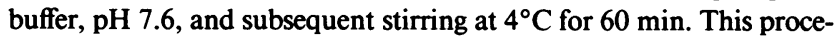
dure, which extracted $\sim 20 \%$ of membrane proteins, has recently been described in detail elsewhere (20). After dilution (1:1) and centrifugation $\left(2,500 \mathrm{~g}\right.$ for $30 \mathrm{~min}$ at $\left.4^{\circ} \mathrm{C}\right)$ the supernatant was passed through an oleate agarose affinity column (14). After washing extensively with $1 \mathrm{M}$ $\mathrm{NaCl}, \mathrm{pH} 8$, bound proteins $(\sim 300 \mathrm{ng}$ ) were eluted with 2 vol of $8 \mathrm{M}$ urea, diluted $4: 1$ and resuspended, after ultrafiltration, in $0.1 \mathrm{M} \mathrm{NaCl}$, $0.01 \mathrm{M}$ phosphate buffer, $\mathrm{pH}$ 7.6. When necessary, the FABP $_{\mathrm{PM}}$ was further purified on a $75 \times 4.6-\mathrm{mm}$ TSK phenyl 5PW HPLC-hydrophobic interaction chromatography column (LKB Instruments, Gaithersburg, MD) using a reverse ammonium sulfate gradient (from $1.2 \mathrm{M}\left(\mathrm{NH}_{4}\right)_{2} \mathrm{SO}_{4}, 0.1 \mathrm{M}$ phosphate, $\mathrm{pH} 6.7$, to $0.1 \mathrm{M}$ phosphate, $\mathrm{pH}$ $6.7 \mathrm{in} 30 \mathrm{~min}$ ) at a flow of $1 \mathrm{ml} / \mathrm{min}$; the absorbance was measured at $220 \mathrm{~nm}$. Purity at various stages of the isolation process was monitored with SDS-polyacrylamide gel electrophoresis (SDS-PAGE), analytical isoelectric focusing, and gel permeation HPLC $(600 \times 7.5-\mathrm{mm}$ TSK $2000 \mathrm{SW}$ column with a $75 \times 7.5-\mathrm{mm}$ precolumn) using an eluting solvent consisting of $0.1 \mathrm{M} \mathrm{NaCl}, 0.01 \mathrm{M}$ phosphate, $\mathrm{pH} \mathrm{6.7, \text {and }}$ measuring ultraviolet (UV) absorbance at $210 \mathrm{~nm}$.

The affinity of the purified FABP $_{\mathrm{PM}}$ for oleate was confirmed by co-chromatography. After being concentrated and resuspended in 0.1 $\mathrm{M} \mathrm{NaCl}, 0.01 \mathrm{M}$ phosphate buffer, $\mathrm{pH} 7.6$, the protein was gently sonicated with $\left[{ }^{3} \mathrm{H}\right]$ oleate $\left(23^{\circ} \mathrm{C}\right.$ for $\left.10 \mathrm{~min}\right)$ and injected into a Superose 12 HPLC-gel permeation column $(300 \times 10 \mathrm{~mm}$, Pharmacia Fine Chemicals, Piscataway, NJ) using the eluting solvent described above at a flow rate of $0.5 \mathrm{ml} / \mathrm{min}$. The collected fractions were counted and the resulting ${ }^{3} \mathrm{H}$ peak compared to the $40-\mathrm{kD}$ protein peak as monitored at $210 \mathrm{~nm}$. The Western blot technique (21) was used to assess the immunologic cross-reactivity between the cardiac FABP $_{P_{M}}$ and an antibody to the rat liver $\mathrm{FABP}_{\mathrm{PM}}$ produced in rabbits as previously described $(14,20)$. The assay was performed on samples subjected to SDS-PAGE (20).

Antibody inhibition studies. The role of the myocardial FABP $\mathrm{PM}_{\mathrm{PM}}$ in oleate uptake was examined by antibody inhibition studies employing the antibody to the rat liver $F_{A B P}$. To avoid possible immunologic and species differences, these studies were conducted with rat heart myocytes; the strong immunologic cross-reactivity between this antibody and rat heart $\mathrm{FABP}_{\mathrm{PM}}$ has been reported previously (20). Isolated rat heart myocytes $\left(1 \times 10^{6} / \mathrm{ml}, 1 \mathrm{ml}\right)$ were incubated for $1 \mathrm{~h}$ at $4^{\circ} \mathrm{C}$ with $500 \mu \mathrm{g}$ of the IgG fraction of the antiserum to rat liver FABP $_{P_{M}}$ or with $500 \mu \mathrm{g}$ of the IgG fraction of the corresponding preimmune serum. The cells were then washed and resuspended in $\mathrm{HH}$ buffer, and aliquots of treated and control cells were incubated at $37^{\circ}$ and $4^{\circ} \mathrm{C}$ with $208 \mu \mathrm{M}\left[{ }^{3} \mathrm{H}\right.$ ]oleate/BSA $(1: 1)$. Initial oleate uptake velocity was determined as described above.

To assess the specificity of the antibody effect, $\left[{ }^{3} \mathrm{H}\right]$ glucose uptake was also studied in aliquots of antibody-treated and control cells. The technique employed involved minor modifications of the one described for oleate uptake: cells were resuspended in Krebs-Ringer buffer containing $10 \mathrm{mM}$ Hepes, and to the mixture of cells and glucose solution (100 $\mu \mathrm{l}$ each) was added a stop solution containing 200 $\mu \mathrm{M}$ phloretin in Krebs-Ringer buffer containing $10 \mathrm{mM}$ Hepes, but no BSA. Initial glucose uptake velocity was calculated from the initial (30-s) linear portion of the cumulative uptake curve.

\section{Results}

\section{Evaluation of methods}

Effectiveness of the stop solution. To allow accurate estimation of initial oleate influx, a stop solution should block bidirectional membrane transport while removing material surface bound but not yet internalized. As previously reported for hepatocytes (8) and adipocytes (10-12), the combination phloretin/BSA is an effective stop solution for use with cardiac myocytes. After preloading of myocytes with $\left[{ }^{3} \mathrm{H}\right]$ oleate for 30 s, $200 \mu \mathrm{M}$ phloretin completely blocked the efflux observed in the presence of buffer alone (Fig. $1 A$ ). Concentrations of BSA of $0.1 \%$ or higher virtually instantly removed surface-bound material followed by progressive efflux of intracellular radioactivity (Fig. $1 \mathrm{~B}$ ). The combined $200 \mu \mathrm{M}$ phloretin/0.1\% BSA stop solution removed surface material while blocking further efflux.

Initial oleate uptake reflects influx rather than dissociation from albumin or intracellular events. Over a wide range of absolute concentrations of oleate and BSA, the concentration of unbound oleate is precisely determined by the oleate/albumin molar ratio $(18,19)$. Nevertheless, at low and nonphysiologic oleate/albumin concentrations the velocity of hepatocellular oleate uptake increases with increasing concentrations of substrate, despite a fixed molar ratio $(22,23)$. Recent experiments in isolated hepatocytes have shown that, for a given molar ratio, there exists a critical concentration of oleate:albumin beyond which further increases in the concentration of substrate complex produce no further increase in oleate uptake velocity (23); this maximal oleate uptake velocity for a given molar ratio was found to be a saturable function of the equilibrium unbound oleate concentrations defined by the various

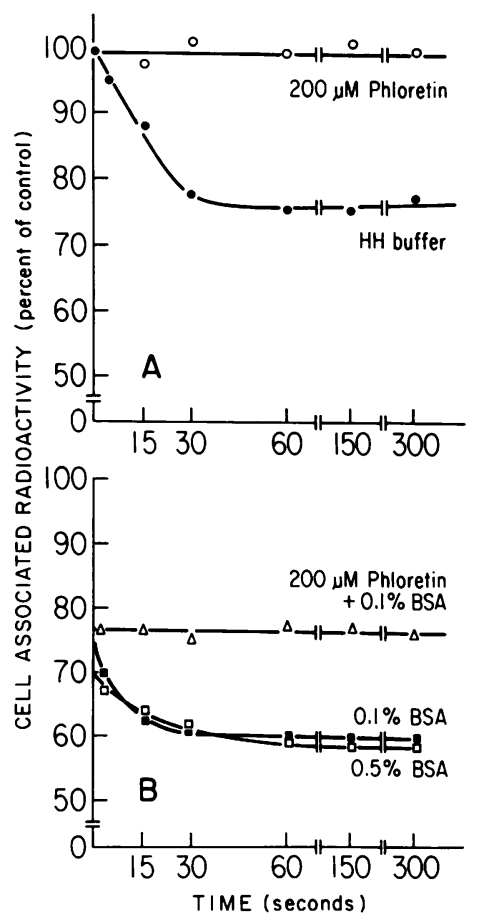

Figure 1. Representative experiment demonstrating the effect of various stop solutions on oleate efflux from canine cardiac myocytes. Cells were incubated for $30 \mathrm{~s}$ with 104:208 $\mu \mathrm{M}$ $\left[{ }^{3} \mathrm{H}\right]$ oleate/BSA. At time zero, the stop solution was added and the cell associated radioactivity monitored over the next $5 \mathrm{~min}$ as described in Methods. Compared to the control buffer $(\bullet)$, phloretin alone (O) blocks oleate efflux $(A)$ while BSA alone $(\boldsymbol{n}, \square)$ virtually instantly reduces the amount of surface bound oleate (lower $y$-axis intercept), while permitting subsequent cellular efflux $(B)$. The combination phloretin/BSA $(\Delta)$ blocks oleate efflux while removing surface bound oleate. 
molar ratios studied (23). This suggests that at low concentrations of oleate/albumin measured uptake rates may be dissociation limited. However, physiologic concentrations of oleate and albumin exceed the observed critical concentrations of oleate/albumin complexes, indicating that, at physiologic concentration of substrate, hepatocellular oleate uptake is, in fact, driven by the equilibrium unbound oleate concentration (23). Under these conditions measured uptake rates reflect cellular removal mechanisms, rather than limited dissociation of substrate complexes $(23,24)$. Analogous experiments in isolated adipocytes (D. Sorrentino and P. D. Berk, unpublished observations) and cardiac myocytes (Fig. 2) yielded similar results. Accordingly, except where specific circumstances dictated otherwise, all experiments in the present paper were conducted at a BSA concentration of $208 \mu \mathrm{M}$, well in excess of the level at which substrate complex dissociation rates or oleate availability are factors which limit uptake velocity. That under the conditions employed uptake velocity was related to the oleate/BSA ratio and consequent unbound oleate concentration, rather than to the total oleate concentration, was corroborated by the finding that oleate uptake was similar at a given ratio whether the ratio was obtained by keeping the BSA concentration constant at $208 \mu \mathrm{M}$ and varying the oleate concentration or by using a fixed $208 \mu \mathrm{M}$ concentration of oleate and varying the BSA concentration (Fig. 3).

Oleate uptake at $37^{\circ} \mathrm{C}$ was linear for at least $40 \mathrm{~s}$. This initial slope of the cumulative oleate uptake curve, which was used to calculate initial oleate uptake velocities, mainly reflects influx rather than intracellular metabolism: removal of glucose from the medium, which decreases esterification up to $50 \%$ (6), did not affect this slope. Finally, uptake rates did not reflect substrate depletion since the initial influx did not exceed $1-2 \%$ of the incubated substrate.

\section{Kinetic characteristics}

Saturability. With canine cardiac myocytes, increasing concentrations of unbound oleate produced saturation of initial

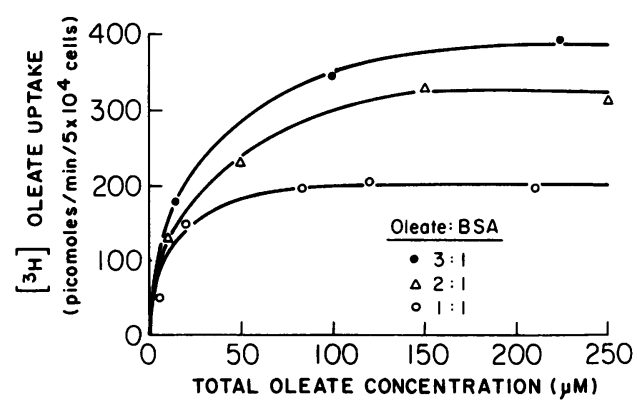

Figure 2. Oleate uptake by canine cardiac myocytes as a function of total oleate concentrations at three representative oleate/BSA molar ratios. Although the equilibrium unbound oleate concentration is constant for a given molar ratio, irrespective of the absolute concentrations of oleate and BSA $(18,19)$ each curve appears to indicate saturation of uptake. However, experiments conducted in isolated hepatocytes and adipocytes have shown that at each oleate/BSA molar ratio the apparent saturation of uptake with increasing total oleate concentrations reflects dissociation limited availability of unbound oleate at low oleate/BSA concentrations and cellular removal at higher oleate/BSA concentrations (23). Accordingly, in subsequent experiments with cardiac myocytes, oleate/BSA concentrations $>150 \mu \mathrm{M}$ were used, at which concentrations measured uptake velocities reflect cellular removal of unbound oleate.

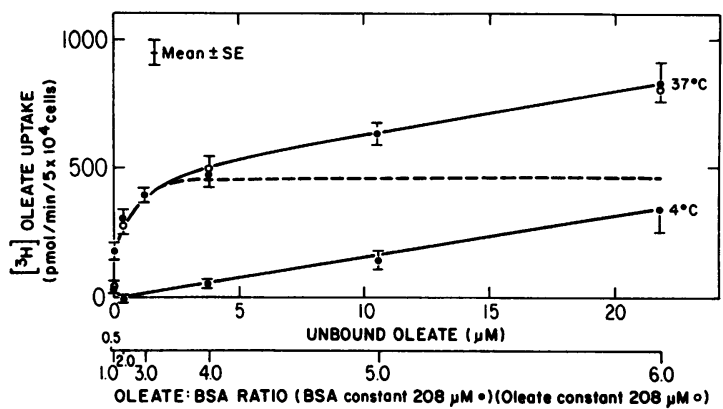

Figure 3. Initial oleate uptake velocities as measured at $37^{\circ} \mathrm{C}$ and $4^{\circ} \mathrm{C}$ from incubation media containing oleate and BSA at oleate/ BSA molar ratios of $0.5: 1$ to $6: 1$. Abscissa also indicates resulting concentrations of unbound oleate, calculated from these molar ratios by the stepwise equilibrium method $(18,19)$. Dashed line, representing specific uptake curve, is the difference between observations at $37^{\circ} \mathrm{C}$ and $4^{\circ} \mathrm{C}$, and was fitted by computer directly to the MichaelisMenten Equation (see text). Error bars indicate standard errors of four to five replicates. Most studies were conducted with $208 \mu \mathrm{M}$ BSA, and varied concentrations of oleate. However, over the range employed in these experiments, uptake velocities for a given molar ratio were the same whether the ratio was achieved by keeping BSA constant and varying the oleate concentrations ( $\bullet$ ) or by keeping oleate constant and varying the BSA concentration (o).

uptake velocity when measured at $37^{\circ} \mathrm{C}$ (Fig. 3). An additional, linear component, believed to represent nonspecific uptake, was apparent at unbound oleate concentrations $>4$ $\mu \mathrm{M}$. It is the only component observed at $4^{\circ} \mathrm{C}$. Although quantitatively important at oleate/BSA ratios $\geq 3: 1$, this linear component is probably insignificant in vivo, where FFA/BSA ratios typically fluctuate between $0.5: 1$ and 2:1 (25). When this linear component was subtracted from the uptake curve observed at $37^{\circ} \mathrm{C}$, a single, saturable process was demonstrated. Computer analysis, conducted as previously described for hepatocytes (26), indicated a $V_{\max }$ of $475 \pm 9$ (SE) pmol/min per 50,000 cells and a $K_{\mathrm{m}}$ of $186 \pm 10 \mathrm{nM}$. Similar results were obtained with rat heart myocytes, in which the specific, saturable component had a $V_{\max }$ of $585 \pm 18 \mathrm{pmol} / \mathrm{min}$ per 50,000 cells and a $K_{\mathrm{m}}$ of $125 \pm 11 \mathrm{nM}$.

Countertransport and trans-stimulation. To demonstrate that myocardial oleate uptake exhibits these additional features of carrier-mediated transport $(27,28) 50-\mu 1$ aliquots of canine cardiac myocytes $\left(1 \times 10^{6} / \mathrm{ml}\right)$ were incubated at $37^{\circ} \mathrm{C}$ with $50 \mu \mathrm{l}$ of $\left[{ }^{3} \mathrm{H}\right]$ oleate/BSA at a molar ratio of 0.1:1 (final concentrations 5:50 $\mu \mathrm{M}$ ), and cell associated radioactivity determined at 10-15-s intervals as described in Methods. After an incubation period of $40 \mathrm{~s}, 2.5 \mathrm{ml}$ of a solution containing $250 \mu \mathrm{M}$ BSA and $0,1,000,1,250$, or $1,500 \mu \mathrm{M}$ unlabeled oleate, with or without $200 \mu \mathrm{M}$ phloretin, was added, and cell associated radioactivity monitored over the next $80 \mathrm{~s}$. A representative set of experiments, employing $1,500 \mu \mathrm{M}$ oleate: 250 $\mu \mathrm{M}$ BSA, is illustrated in Fig. $4 A$. In contrast to control cells, which continue to accumulate $\left[{ }^{3} \mathrm{H}\right]$ oleate, addition of unlabeled oleate/BSA in the presence of phloretin blocks subsequent influx and efflux of $\left[{ }^{3} \mathrm{H}\right]$ oleate, resulting in a constant level of cell associated radioactivity over the subsequent $80 \mathrm{~s}$. By contrast, addition of the same unlabeled oleate/albumin solution in the absence of phloretin results in progressive efflux of $\left[{ }^{3} \mathrm{H}\right]$ oleate at a rate of $1.21 \pm 0.14 \mathrm{pmol} / \mathrm{min}$ per $5 \times 10^{4}$ myocytes. From the cell-associated radioactivity at $40 \mathrm{~s}$, the 

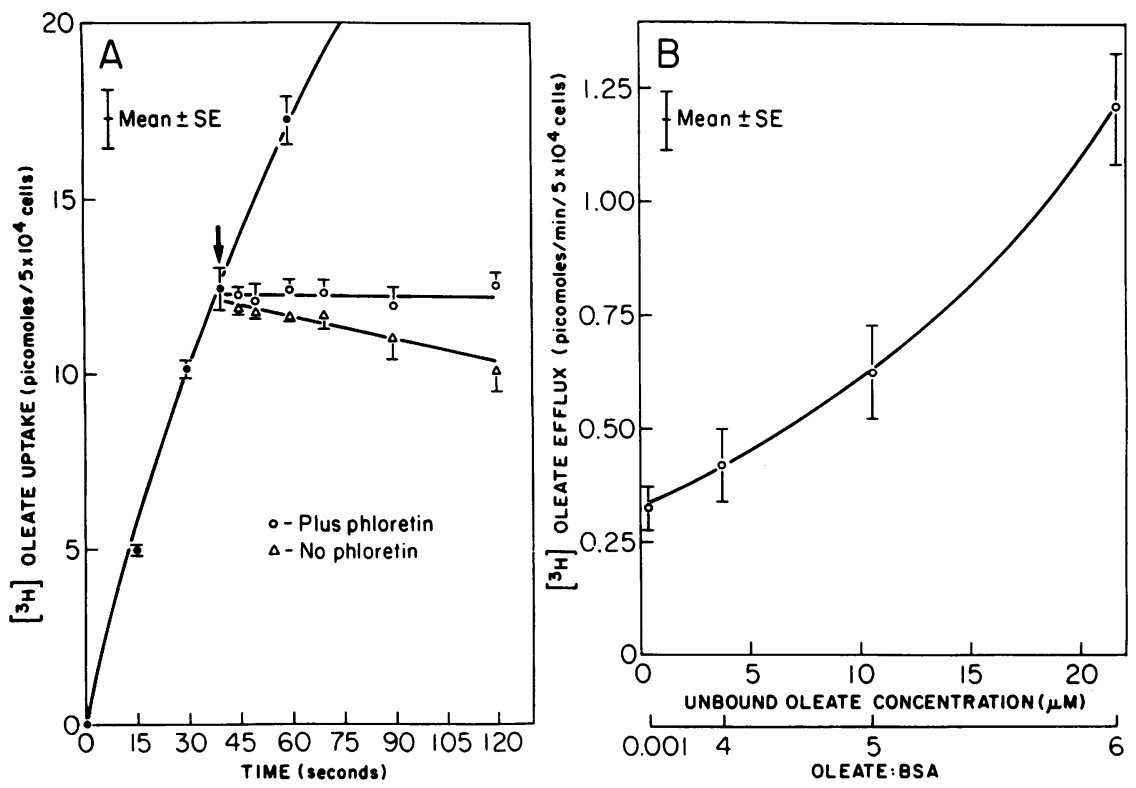

Figure 4. Countertransport and trans-stimulation of $\left[{ }^{3} \mathrm{H}\right]$ oleate efflux in isolated canine cardiomyocytes. (A) $50 \mu \mathrm{l}$ of $\left[{ }^{3} \mathrm{H}\right]$ oleate/BSA $(5: 50 \mu \mathrm{M})$ was added to $50 \mu \mathrm{l}$ of cells and cell-associated radioactivity determined at various times as described in Methods. Control cells were incubated for $120 \mathrm{~s}(\bullet)$. In the experimental incubations $2.5 \mathrm{ml}$ of unlabeled oleate/BSA $(1,500: 250 \mu \mathrm{M})$ with (0) or without $(\Delta) 200 \mu \mathrm{M}$ phloretin, was added to the cells after 40-s incubation with the isotope (arrow), and the cell associated radioactivity monitored over the next $80 \mathrm{~s}$. The figure shows that efflux of $\left[{ }^{3} \mathrm{H}\right]$ oleate occurs against the prevailing concentration gradient (see text) while phloretin virtually abolishes the phenomenon. $(\overline{\mathrm{x}} \pm \mathrm{SE}, n=3)$. $(B)\left[{ }^{3} \mathrm{H}\right]-$ oleate efflux rates measured under the conditions described for $A$, are plotted versus the extracellular unlabeled oleate/BSA molar ratios and consequent unbound oleate concentrations following addition of unlabeled oleate:albumin solutions containing no phloretin. Under these conditions $\left[{ }^{3} \mathrm{H}\right]$ oleate efflux increases with increasing extracellular unbound oleate. In the presence of phloretin efflux was minimal at all unbound oleate concentrations studied (see text). packed cell volume in the incubation mixture $(10 \mu \mathrm{l})$ and an assumed cellular water space of $50 \%$, the average intracellular $\left[{ }^{3} \mathrm{H}\right]$ oleate concentration at $40-\mathrm{s}$ incubation is estimated at $\sim 3.0 \mu \mathrm{M}$. By contrast, the extracellular free unlabeled oleate concentration after addition of the $1,500 \mu \mathrm{M}$ oleate: $250 \mu \mathrm{M}$ BSA is $21.9 \mu \mathrm{M}(18,19)$. Hence, this experiment illustrates phloretin-inhibitable efflux of $\left[{ }^{3} \mathrm{H}\right]$ oleate from cardiac myocytes against a sevenfold concentration gradient. Even if intracellular oleate is compartmentalized at concentrations in excess of that calculated above, it is unlikely that the concentrations would be sufficient to completely abolish the inwardly directed oleate concentration gradient established by the experimental manipulations. Aside from establishing an inwardly directed oleate concentration gradient, the relative volumes and concentrations of the labeled and unlabeled oleate solutions employed abruptly reduce the specific activity of extracellular oleate, minimizing further uptake of $\left[{ }^{3} \mathrm{H}\right]$ oleate and therefore the possible effects on cell associated radioactivity of displacement of labeled substrate from its albumin carrier.

As illustrated in Fig. $4 \mathrm{~B}$, in the absence of phloretin, $\left[{ }^{3} \mathrm{H}\right]$ oleate efflux rates were found to increase with increasing oleate/albumin ratios, and hence, with increasing unbound oleate concentrations, in the unlabeled oleate:albumin solutions added at $40 \mathrm{~s}$. This indicates trans-stimulation of $\left[{ }^{3} \mathrm{H}\right]-$ oleate efflux by extracellular oleate. The efflux rates in the absence of phloretin exceeded in all cases those observed in the presence of phloretin which averaged $0.15 \pm 0.10 \mathrm{pmol} / \mathrm{min}$ per $5 \times 10^{4}$ cells, and did not differ as a function of the oleate/albumin solution employed (data not shown).

Oleate uptake in the presence of various inhibitors and ions. In canine cardiac myocytes, as in hepatocytes $(8,9)$, phloretin $(400 \mu \mathrm{M})$ and trypsin $(0.3 \mathrm{mg} / \mathrm{ml})$ significantly inhibited oleate uptake to $27 \pm 3$ and $64 \pm 3 \%$, (both $P<0.005$ ) respectively, of control. KCN (1 mM), CCCP (100 $\mu \mathrm{M})$, and ouabain (1 mM), which all decrease hepatocellular uptake of oleate (9), had no effect in myocytes under the conditions employed. Total or partial substitution of $\mathrm{NaCl}$ in the medium with $\mathrm{LiCl}$, choline $\mathrm{Cl}, \mathrm{KCl}$ or sucrose, which decreases fatty acid uptake in hepatocytes (9), stimulated uptake in myocytes by $15-55 \%$ (significant, $P<0.01$, for $\mathrm{LiCl}$ and choline $\mathrm{Cl}$ ).

Isolation of a $F A B P_{P M}$

Preliminary efforts to isolate a canine cardiac myocyte FABP $_{\mathbf{P M}}$ in appreciable quantities directly from crude heart homogenate, utilizing the combination of preparative isoelectric focusing and affinity chromatography successfully employed for FABP $_{\mathrm{PM}}$ from other tissues (20), were complicated by the presence of relatively large quantities of contaminating proteins in such homogenates. Furthermore, due to the large proportion of endothelial cells, the possibility exists that plasma membranes from homogenates may not entirely represent sarcolemma preparations. Accordingly the small scale procedure starting from isolated myocytes described in Methods was employed instead. Although the resulting quantities of membrane proteins were too small to employ preparative isoelectric focusing, a combination of affinity chromatography and HPLC procedures including hydrophobic interaction chromatography, successfully purified the protein of interest to homogeneity.

When applied to plasma membranes from isolated canine cardiac myocytes, the procedures for extraction and oleate agarose affinity chromatography of $\mathrm{FABP}_{\mathrm{PM}}$ yielded a major band on SDS-polyacrylamide gel electrophoresis having the same molecular mass as the $\mathrm{FABP}_{\mathrm{PM}}$ isolated from rat liver, adipose tissue, jejunum, and myocardium (20) (Fig. 5). In contrast to the latter proteins, which are readily purified to homogeneity (20), the canine protein was frequently accompanied by a contaminant of either slightly greater (Fig. 5) or lesser molecular 


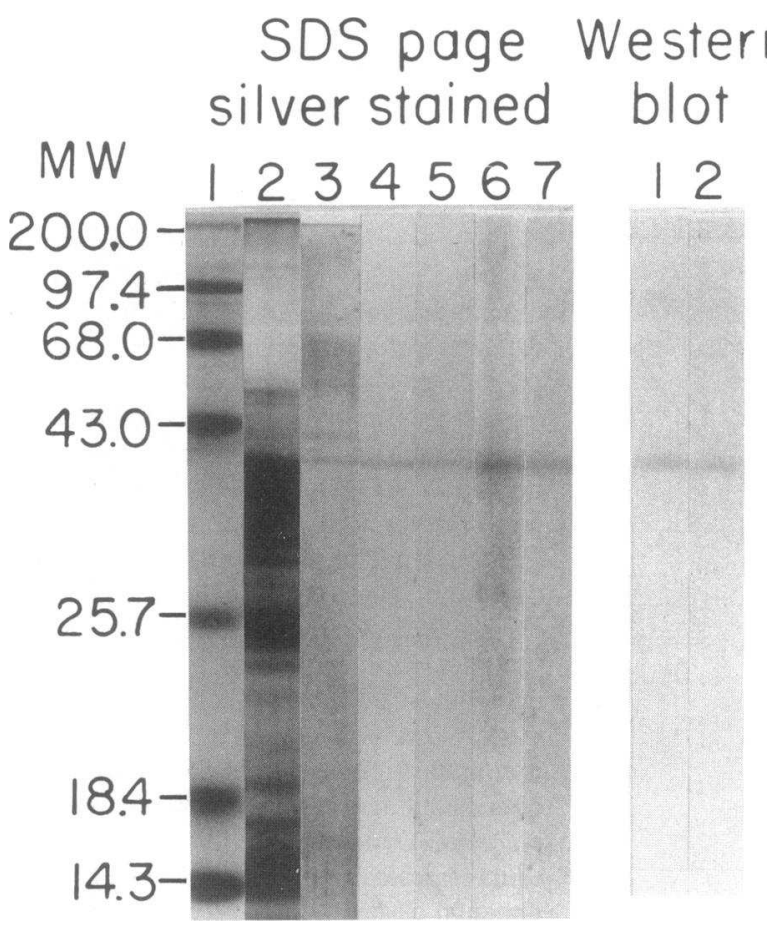

Figure 5. (Left) SDS-PAGE of membrane proteins. Standards (1), total canine myocardial membrane proteins (2) and proteins purified by oleate agarose affinity chromatography from dog heart (3) and rat liver (4), adipose tissue (5), jejunum (6), and heart (7). MW, molecular weight (kD). (Right) Western blot of rat hepatocyte and canine myocyte $F_{A B P} P_{P M}$ against the antibody to the rat hepatocyte FABP $_{\mathrm{PM}}$. The myocyte $\mathrm{FABP}_{\mathrm{PM}}$, isolated by affinity chromatography, had been further purified by hydrophobic interaction HPLC.

weight, which appeared as a shoulder on the gel permeation HPLC elution peak (Fig. $6 \mathrm{~A}$ ). When further purified, as described, by hydrophobic interaction HPLC, the FABP $P_{P M}$ eluted from the gel permeation column as a single, symmetrical peak at an elution time of $32.5 \mathrm{~min}$. After incubation with $\left[{ }^{3} \mathrm{H}\right]$ oleate, rechromatography of the eluted canine $\mathrm{FABP}_{\mathrm{PM}}$ through a $300 \times 10-\mathrm{mm}$ Superose-12 HPLC gel permeation column again yielded a symmetric peak which co-chromatographed with the labeled fatty acid; its retention time corresponded to a molecular weight of $40 \mathrm{kD}$ (Fig. $6 \mathrm{~B}$ ). In addition to a molecular weight $(40 \mathrm{kD})$ and isoelectric point (pI 9.1) similar to those of the other FABP $_{\mathrm{PM}}$ previously reported, the canine cardiac myocyte FABP $_{\mathrm{PM}}$ gave a positive Western blot with a rabbit antiserum raised against the rat liver ${ } A B P_{P M}$ (Fig. 5).

\section{Antibody inhibition studies}

At $37^{\circ} \mathrm{C}$ the antibody to rat liver $\mathrm{FABP}_{\mathrm{PM}}$ significantly inhibited uptake of $\left[{ }^{3} \mathrm{H}\right]$ oleate into isolated rat heart myocytes, compared to cells treated with preimmune serum $(216 \pm 2$ vs. $358 \pm 34 \mathrm{pmol} / \mathrm{min}$ per 50,000 cells, $P<0.02$ ) (Fig. 7). The degree of inhibition at $37^{\circ} \mathrm{C}(40 \%)$ was similar to that in adipocytes treated with corresponding antibody concentrations (12). By contrast, the antibody had no effect compared to preimmune serum on nonspecific oleate uptake at $4^{\circ} \mathrm{C}$, $(2.7 \pm 0.10$ vs. $2.9 \pm 0.9 \mathrm{pmol} / \mathrm{min}$ per 50,000 cells, $P>0.5)$. Antibody-treated cells retained their predominantly rod shape and viability. Specificity of the antibody effect for oleate trans- port was indicated by the glucose uptake studies: uptake of 5 $\mu \mathrm{M}$ glucose in treated and control cells was identical (15.3 \pm 2.4 vs. $16.0 \pm 0.6 \mathrm{pmol} / 5 \mathrm{~min}$ per $10^{6}$ cells, $P>0.5$ ) (Fig. 7).

\section{Discussion}

Fatty acid uptake by cardiac myocytes as well as other cell types was long considered by many $(5,6,29-31)$ although not all investigators $(3,4)$ to occur by diffusion rather than by a specific facilitated process. Unfortunately, these earlier experiments with cardiac myocytes could not satisfactorily quantify FFA influx, since the techniques employed did not block efflux during sample preparation and the cells were prepared and used without calcium, which has been shown to alter sarcolemma integrity and permeability (7).

More recently, we and others have shown that FFA uptake has the kinetic characteristics of a carrier-mediated process in hepatocytes $(8,9)$ and adipocytes $(10-12)$, and have isolated and characterized basic, $40-\mathrm{kD}$ FABP ${ }_{\mathrm{PM}}$ from these and other tissues with high transmembrane fluxes of fatty acids $(13,14$, 20). That these proteins are similar and mediate FFA uptake has been clearly demonstrated. By immunofluorescence, an antibody raised in rabbits against the rat liver $F_{A B P} P_{P M}$ bound specifically to the plasma membranes of cardiac myocytes, adipocytes, and jejunal enterocytes (12-14). This antibody also inhibited oleate uptake, noncompetitively and in a dosedependent fashion, in rat hepatocytes (9), adipocytes (12) and, in preliminary studies, in the gut (15). As these data collectively suggested that FFA might be taken up by the heart by mechanisms similar to those of liver, adipose tissue and gut, the current study, initiated in 1986 (16), focused on cardiac myocytes.

The cells employed, isolated from dog and rat, have been shown to resemble intact myocardium, functionally and morphologically, and to conform to the definition of " $\mathrm{Ca}^{2+}$-tolerant" $(7,17)$. We employed a well-validated rapid filtration technique and a $200 \mu \mathrm{M}$ phloretin:0.1\% BSA stop solution, which permits accurate quantitation of cellular influx by blocking bidirectional membrane transport of oleate (8-12) while removing material surface bound but not yet internalized $(8,9,12)$. That removal of glucose from the medium, which decreases esterification in these cells by up to $50 \%(6)$, did not affect initial uptake velocity suggests that this parameter reflects principally the activity of membrane transport processes rather than an intracellular process such as esterification. Experiments analogous to those performed in other cell types (23) confirmed that myocyte oleate uptake is driven by the equilibrium unbound oleate concentration, rather than by the total oleate concentration.

Initial oleate uptake velocity was saturable with increasing concentrations of unbound oleate; after subtraction of a nonspecific linear component it conformed to Michaelis-Menten kinetics with a $V_{\max }$ of $585 \mathrm{pmol} / \mathrm{min}$ per 50,000 cells and a $K_{\mathrm{m}}$ of $125 \mathrm{nM}$ for rat cardiomyocytes. In canine cardiomyocytes, isolated from an animal with a lower overall metabolic and heart rate, $V_{\max }$ was not surprisingly somewhat lower at $\mathbf{4 7 5}$ $\mathrm{pmol} / \mathrm{min}$ per 50,000 cells. In vivo experiments performed with the indicator dilution technique in the dog by Rose and Goresky (1) offer the opportunity to compare FFA influx rates in the working heart with those in the isolated, resting cells. Based on an average heart interstitial space of 13-14\% (2) and 

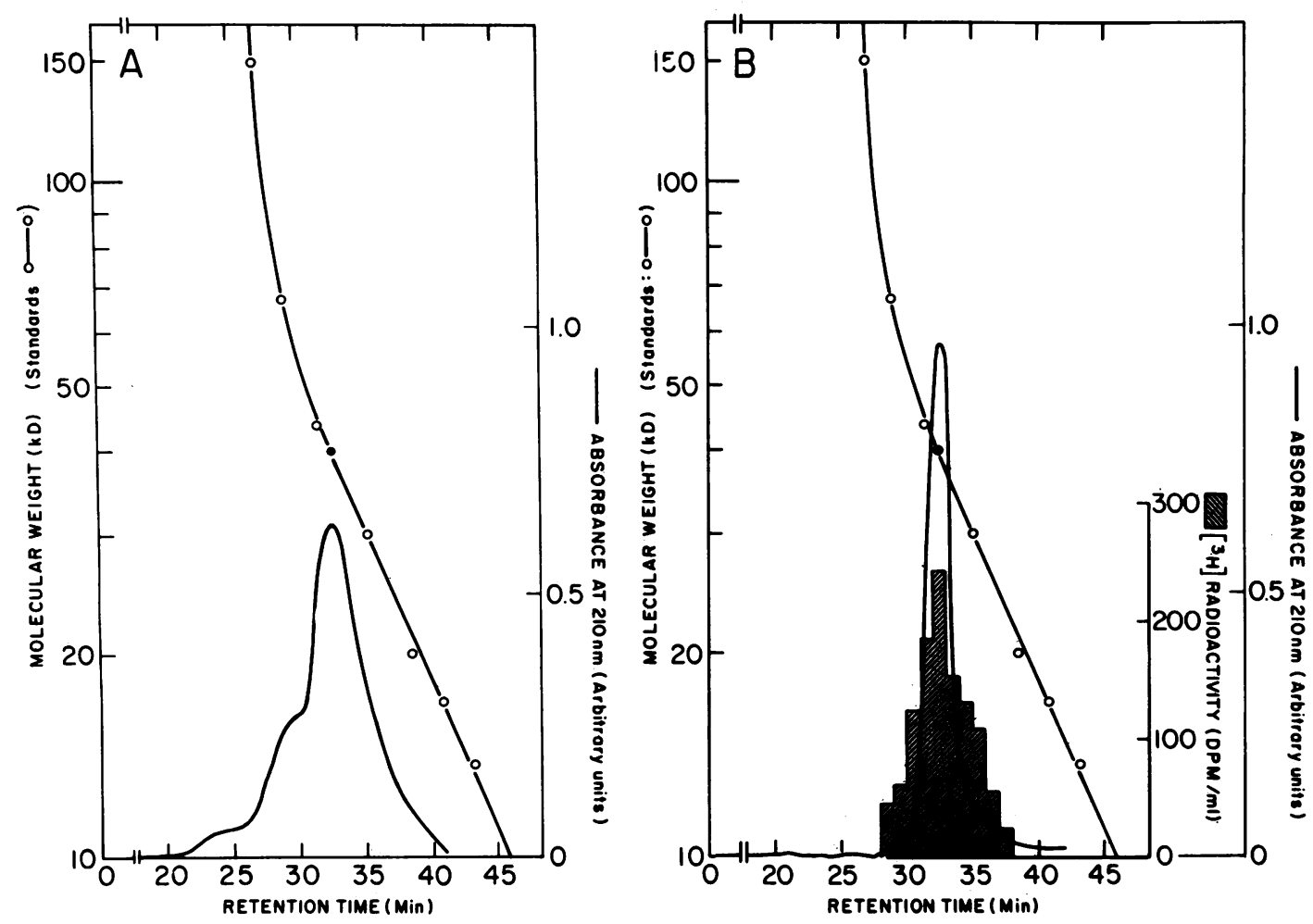

Figure 6. HPLC gel permeation elution profile of the canine myocardial FABP $\mathrm{PM}_{\mathrm{PM}}$ isolated by affinity chromatography before $(A)$ and after $(B)$ further purification by hydrophobic interaction chromatography (for details see text). $B$ also shows co-chromatography of the protein with $\left[{ }^{3} \mathrm{H}\right]-$ oleate at a retention time corresponding to a molecular weight of $40 \mathrm{kD}$.

on an average cell number of $40-50 \times 10^{6} / \mathrm{g}$ heart $(7,32)$, it can be calculated that in vivo, at FFA/BSA molar ratios of $\sim 0.5: 1$ to $1: 1$, FFA influx approximates $1-1.5 \mathrm{nmol} / \mathrm{min}$ per 50,000 cells, a value three to five times larger than we observed in isolated cardiomyocytes. While other interpretations are possible, this discrepancy may indicate that FFA influx is dependent on the working load, and as a consequence, that the cardiomyocyte FFA requirements may be modulated at the membrane level. This conclusion is corroborated by the finding that, at low ventricular load, palmitate uptake rates in perfused rat heart are comparable to the data obtained in rat myocytes in the present study (33).

Shortly after our initial characterization of a rat myocardial FABP $_{\mathrm{PM}}$ (20) Stremmel reported that an antibody to this protein inhibited saturable oleate uptake in isolated rat heart myocytes (34). However, his reported maximal oleate uptake

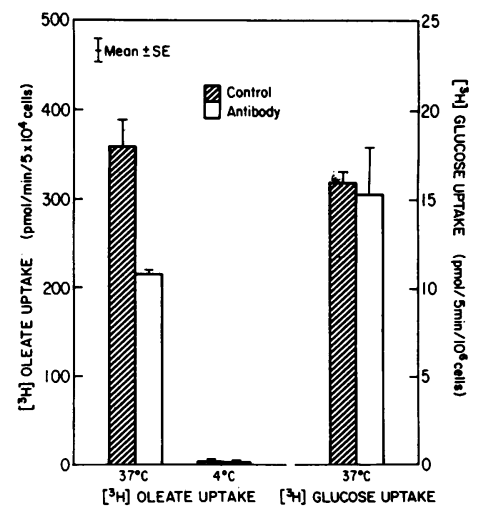

Figure 7. Influence of a rabbit antibody to rat liver FABP $_{\mathrm{PM}}$ on uptake by isolated rat heart myocytes of $\left[{ }^{3} \mathrm{H}\right]$ oleate and $\left[{ }^{3} \mathrm{H}\right]$ glucose. The antibody inhibited carrier-mediated oleate uptake $\left(37^{\circ} \mathrm{C}\right)$, but had no effect on nonspecific oleate uptake $\left(4^{\circ} \mathrm{C}\right)$ or on glucose uptake ( $\overline{\mathrm{x}} \pm \mathrm{SE}, n=3)$. velocity, $95 \mathrm{pmol} / \mathrm{min}$ per 50,000 cells, is surprisingly low for an animal with the metabolic rate of the rat and does not correspond to earlier studies of fatty acid removal rates in this species (33). Moreover, it is increasingly apparent that saturable uptake is a necessary but not sufficient criterion to establish that a transport process is carrier mediated (24). In the current report we demonstrate that myocyte oleate uptake also displays countertransport and trans-stimulation, two other important features of carrier-mediated transport $(27,28)$. Countertransport is typically established by demonstrating cellular efflux of labeled compound against the prevailing concentration gradient upon addition of unlabeled compound to the incubation mixture (27). Demonstration of countertransport, however, is rendered difficult if the substance under study, like oleate, is tightly albumin bound because the added unlabeled species may displace the label from its protein binding sites in the incubation mixture, thereby increasing its free concentration and promoting its uptake. This phenomenon, described by Goresky et al. (35) for the hepatic uptake of palmitate, may in turn result in increased influx of the labeled species rather than demonstrating its predicted efflux from the cells (35-37). We reasoned that if the amount of unlabeled oleate added sufficiently exceeded the amount of extracellular $\left[{ }^{3} \mathrm{H}\right]$ oleate present, the resulting isotopic dilution of extracellular label would insure that subsequent influx of $\left[{ }^{3} \mathrm{H}\right]$ oleate would be negligible. Under these circumstances it would be possible to follow the efflux of the internalized label from the cell by measurements of cellular radioactivity. These predictions were confirmed by the experiment illustrated in Fig. $4 A$, which also shows that phloretin, which blocks membrane transport of oleate (Fig. 1), virtually abolished the efflux of the labeled 
species. Furthermore, as expected $(27),\left[{ }^{3} \mathrm{H}\right]$ oleate efflux rates under these conditions were trans-stimulated by increasing extracellular concentrations of unbound, unlabeled oleate (Fig. $4 \mathrm{~B}$ ).

By analogy with hepatocyte $(8,9)$ and adipocyte $(10-12)$ studies, $\left[{ }^{3} \mathrm{H}\right]$ oleate uptake was inhibited by phloretin and a protease, trypsin, suggesting that the carrier is a protein. A basic $40-\mathrm{kD}$ protein which co-chromatographs with oleate was subsequently isolated from cardiac myocyte plasma membranes by procedures including oleate-agarose affinity chromatography, a technique previously employed to isolate analogous $\mathrm{FABP}_{\mathrm{PM}}$ from hepatocytes (14), adipocytes $(12,20)$, and jejunal enterocytes (13). These proteins are unrelated structurally or immunologically to the family of cytosolic fatty acid binding proteins previously described in these tissues (38). The $\mathrm{FABP}_{\mathrm{PM}}$ of rat liver, gut, adipose tissue, and myocardium are closely related, if not identical (20), and, in antibody inhibition studies, have now all been shown to play a crucial role in specific fatty acid uptake in their respective tissues $(9,12,15)$. In the present study; an antibody against rat liver ${ }{ }_{A B P} P_{P M}$ gave a positive Western blot with the canine cardiac FABP ${ }_{P M}$ and significantly inhibited specific $\left[{ }^{3} \mathrm{H}\right]$ oleate uptake by rat myocytes at $37^{\circ} \mathrm{C}$, while having no effect on nonspecific oleate uptake as measured at $4^{\circ} \mathrm{C}$. Moreover, the antibody did not inhibit myocyte uptake of glucose, which has also been shown under similar conditions to be a specific carrier-mediated process (39), thus demonstrating the selectivity of the antibody effect.

Despite these similarities, the transport processes do not appear fully identical. Fatty acid uptake in liver and gut has been reported to be potential sensitive (40), sodium coupled, and ouabain inhibitable $(9,15)$. Recent, preliminary studies in the perfused liver suggest that oleate uptake is actively driven by both the electrical and sodium chemical gradients across the plasma membrane (41). However, neither removal of external sodium nor ouabain nor metabolic inhibitors appear to inhibit significantly oleate uptake in adipocytes (10-12); the previously mentioned study by Stremmel (34) failed to demonstrate sodium dependence of myocyte oleate uptake; in the present study, substitution of external $\mathrm{Na}^{+}$with $\mathrm{Li}^{+}, \mathrm{K}^{+}$, choline, or sucrose in fact stimulated oleate uptake in cardiac myocytes. Previous observations in cultured chick embryo cardiac myocytes also indicated that fatty acid uptake occurs by a facilitation process without energy dependence (4). The basis for these differences remains to be determined. Preliminary studies conducted in our laboratory suggest (42) that the $\mathrm{Na}^{+}$ requirement of oleate uptake may be dependent on particular experimental conditions. Another possible explanation is that, as with the well-characterized 43-kD FABP $\mathrm{PM}_{\mathrm{PM}}$ of Escherichia coli $(43,44)$, the $\mathrm{FABP}_{\mathrm{PM}}$ isolated thus far from mammalian tissues act as acceptors in more complex transport systems involving additional protein components. These additional transport components, and the consequent energy and ion requirements, could be tissue specific. These and other hypotheses are currently being explored.

Despite these questions, the preponderance of evidence from several laboratories now argues against the hypothesis that myocardial fatty acid uptake occurs by diffusion, and strongly suggests that the process is a facilitated one, mediated by a specific plasma membrane protein with high affinity for long-chain FFA, analogous to those isolated from liver, gut, and adipose tissue. Hence, both the absorption and the dispo- sition of FFA may be subject to regulation at the level of the plasma membrane.

\section{Acknowledgments}

The authors wish to thank Dr. Luis M. Isola for assistance with the curve fitting procedures and Ms. Mary Barrett for preparation of the manuscript.

This research was supported by National Institutes of Health grants AM-26438, HL-30557, HL-33655, and AA-06860, grants from Regione Sardegna, Assessorato P.I. Italy and the New York Heart Association, and gifts from the Jack Martin Fund, the Polly Annenberg Levee Charitable Trust, and the Monique Weil-Caulier Bequest.

\section{References}

1. Rose, C. P., and C. A. Goresky. 1977. Constraints on the uptake of labeled palmitate by the heart. Circ. Res. 41:534-545.

2. Rose, C. P., C. A. Goresky, and G. G. Bach. 1977. The capillary and sarcolemmal barriers in the heart: an exploration of labeled water permeability. Circ. Res. 41:515-533.

3. Samuel, D., S. Paris, and G. Ailhaud. 1976. Uptake and metabolism of fatty acids and analogues by cultured cardiac cells from chick embryo. Eur. J. Biochem. 64:583-595.

4. Paris, S., D. Samuel, G. Romey, and G. Ailhaud. 1979. Uptake of fatty acids by cultured cardiac cells from chick embryo: evidence for a facilitation process without energy dependence. Biochimie. 61:361367.

5. DeGrella, R. F., and R. J. Light. 1980. Uptake and metabolism of fatty acids by dispersed adult rat heart myocytes. I. Kinetics of homologous fatty acids. J. Biol. Chem. 255:9731-9738.

6. DeGrella, R. F., and R. J. Light. 1980. Uptake and metabolism of fatty acids by dispersed adult rat heart myocytes. II. Inhibition by albumin and fatty acid homologues, and the effect of temperature and metabolic reagents. J. Biol. Chem. 255:9739-9745.

7. Wittenberg, B. A., and T. F. Robinson. 1981. Oxygen requirements, morphology, cell coat and membrane permeability of calciumtolerant myocytes from hearts of adult rats. Cell Tissue Res. 216:231251.

8. Stremmel, W., and P. D. Berk. 1986. Hepatocellular influx of $\left[{ }^{14} \mathrm{C}\right]$ oleate reflects membrane transport rather than intracellular metabolism or binding. Proc. Natl. Acad. Sci. USA. 83:3086-3090.

9. Stremmel, W:, G. Strohmeyer, and P. D. Berk. 1986. Hepatocellular uptake of oleate is energy dependent, sodium-linked, and inhibited by an antibody to a hepatocyte plasma membrane fatty acid binding protein. Proc. Natl. Acad. Sci. USA 83:3584-3588.

10. Abumrad, N. A., R. H. Perkins, J. H. Park, and C. R. Park. 1981. Mechanism of long chain fatty acid permeation in the isolated adipocyte. J. Biol. Chem. 256:9183-9191.

11. Abumrad, N. A., J. H. Park, and C. R. Park. 1984. Permeation of long-chain fatty acid into adipocytes. J. Biol. Chem. 259:89458953.

12. Schweiterman, W., D. Sorrentino, B. J. Potter, J. Rand, C.-L. Kiang, D. Stump and P. D. Berk. 1988. Uptake of oleate by isolated rat adipocytes is mediated by a $40 \mathrm{kDa}$ plasma membrane fatty acid binding protein closely related to that in liver and gut. Proc. Natl. Acad. Sci. USA. 85:359-363.

13. Stremmel, W., G. Lotz, G. Strohmeyer, and P. D. Berk. 1985. Identification, isolation, and partial characterization of a fatty acid binding protein from rat jejunal microvillous membranes. J. Clin. Invest. 75:1068-1076.

14. Stremmel, W., G. Strohmeyer, F. Borchard, S. Kochwa, and P. D. Berk. 1985. Isolation and partial characterization of a fatty acid binding protein from rat liver plasma membranes. Proc. Natl. Acad. Sci. USA. 82:4-8. 
15. Stremmel, W. 1987. Uptake of fatty acids by the jejunal mucosa is mediated by a specific fatty acid binding membrane protein. Gastroenterology. 92:1656 (Abstr.)

16. Sorrentino, D., R. Robinson, C.-L. Kiang, D. Stump, B. J. Potter, and P. D. Berk. 1987. Mechanisms of oleate uptake by isolated cardiac myocytes. Clin. Res. 35:575A. (Abstr.)

17. Hewett, K., M. J. Legato, P. Danilo, and R. B. Robinson. 1983 Isolated myocytes from adult canine left ventricle: $\mathrm{Ca}^{2+}$ tolerance, electrophysiology, and ultrastructure. Am. J. Physiol. 245:H830H839.

18. Wosilait, W. D., and P. Nagy. 1976. A method of computing drug distribution in plasma using stepwise association constants. Clofibrate as an illustrative example. Comput. Programs Biomed. 6:142148.

19. Spector, A. A., J. E. Fletcher, and J. D. Ashbrook. 1971. Analysis of long-chain free fatty acid binding to bovine serum albumin by determination of stepwise equilibrium constants. Biochemistry. 10:3229-3232.

20. Potter, B. J., D. Stump, W. Schwieterman, D. Sorrentino, N. Jacobs, C.-L. Kiang, J. H. Rand, and P. D. Berk. 1987. Isolation and partial characterization of plasma membrane fatty acid binding proteins from myocardium and adipose tissue and their relationship to analogous proteins in liver and gut. Biochem. Biophys. Res. Commun. 148:1370-1376.

21. Towbin H., T. Staehelin, and J. Gordon. 1979. Electrophoretic transfer of proteins from polyacrylamide gels to nitrocellulose sheets: procedure and some applications. Proc. Natl. Acad. Sci. USA. 76:4350-4354.

22. Weisiger, R., J. Gollan, and R. Ockner. 1981. Receptor for albumin on the liver cell may mediate uptake of fatty acids and other albumin bound substances. Science (Wash. DC). 211:1048-1051.

23. Sorrentino, D., C.-L. Kiang, and P. D. Berk. 1988. At physiologic albumin concentrations hepatocellular oleate uptake is driven by the equilibrium unbound oleate concentration. Gastroenterology. 94:593. (Abstr.)

24. Weisiger, R. A. 1985. Dissociation from albumin: a potentially rate-limiting step in the clearance of substances by the liver. Proc. Natl. Acad. Sci. USA. 82:1563-1567.

25. Spector, A. A. 1986. Plasma albumin as a lipoprotein. In Biochemistry and Biology of Plasma Lipoproteins. A. Scanu and A. A. Spector, editors. Marcel Dekker, Inc., New York. 247-279.

26. Stremmel, W., and P. D. Berk. Hepatocellular uptake of sulfobromophthalein and bilirubin is selectively inhibited by an antibody to the liver plasma membrane sulfobromophthalein/bilirubin binding protein. J. Clin. Invest. 78:822-826.

27. LeFevre, P. G. 1975. The present state of the carrier hypothesis. Curr. Top. Membr. Transp. 7:109-215.

28. Scharschmidt, B. F., and J. L. Gollan. 1979. Current concepts of bilirubin metabolism and hereditary hyperbilirubinemia. In Progress in Liver Disease. H. Popper and F. Schaffner, editors. Grune \& Stratton, New York. 187-212.

29. Heimberg, M., E. H. Goh, H. J. Lausner, C. Soler-Argilaga, J.
Weinstein, and H. G. Wilcox. 1978. Regulation of hepatic metabolism of free fatty acids: interrelationships among secretion of very-low-density lipoproteins, ketogenesis, and cholesterogenesis. In Disturbances in Lipid and Lipoprotein Metabolism. J. M. Dietschy, A. M. Gotto, and J. A. Ontko, editors. Williams \& Wilkins Co., Baltimore. 251-267.

30. Spector, A. A., and J. E. Fletcher. 1978. Transport of fatty acid in the circulation. In Disturbances in Lipid and Lipoprotein Metabolism. J. M. Dietschy, A. M. Gotto, and J. A. Ontko, editors. Williams \& Wilkins Co., Baltimore. 229-249.

31. Kuhl, W. E., and A. A. Spector. 1970. Uptake of long-chain fatty acid methyl esters by mammalian cells. J. Lipid Res. 11:458-465.

32. Anversa, P., A. V. Loud, F. Giacomelli, and J. Wiener. 1978. Absolute morphometric study of myocardial hypertrophy in experimental hypertension. II. Ultrastructure of myocytes and interstitium. Lab. Invest. 5:597-609.

33. Neely, J. R., M. J. Rovetto, and J. F. Oram. 1972. Myocardial utilization of carbohydrate and lipids. Prog. Cardiovasc. Dis. 3:289329.

34. Stremmel, W. 1988. Fatty acid uptake by isolated rat heart myocytes represents a carrier-mediated transport process. J. Clin. Invest. 81:844-852.

35. Goresky, C. A., G. G. Bach, D. S. Daly, S. Mishkin, and I. M. Arias. 1978. Uptake of labeled palmitate by the intact liver: role of intracellular binding sites. Am. J. Physiol. 234:E542-E553.

36. Goresky, C. A., A. W. Wolkoff, C. P. Rose, and D. Cousineau. 1985. Sequestered tracer outflow recovery in multiple indicator dilution experiments. Hepatology. 5:805-814.

37. Goresky, C. A., G. G. Bach, C. P. Rose, and A. W. Wolkoff. 1986. Correspondence: The exponential extrapolation area test: no surprises. Hepatology. 6:545-546.

38. Bass, N. M. 1985. Function and regulation of hepatic and intestinal fatty acid binding proteins. Chem. Phys. Lipids. 38:95-114.

39. Gerards, P., W. Graf, and H. Kammermeier. 1982. Glucose transfer studjes in isolated cardiocytes of adult rats. J. Mol. Cell. Cardiol. 14:141-149.

40. Stremmel, W. 1987. Translocation of fatty acids across the basolateral rat liver plasma membrane is driven by an active potential-sensitive sodium dependent transport system. J. Biol. Chem. 262:6284-6289.

41. Weisiger, R. A., J. G. Fitz, and B. F. Scharschmidt. 1987. Hepatic oleate uptake: electrochemical driving forces. Clin. Res. 35:416A. (Abstr.)

42. Sorrentino, D., W. Schwieterman, C.-L. Kiang, T. McHugh, and P. D. Berk. 1987. The hepatocellular uptake of free fatty acids does not involve a sodium-fatty acid symport. Hepatology. 7:1036. (Abstr.)

43. Nunn, W. D., R. W. Colburn, and P. N. Black. 1986. Transport of long-chain fatty acids in Escherichia Coli. J. Biol. Chem. 261:167171.

44. Spratt, S. K., P. N. Black, M. M. Ragozzino, and W. D. Nunn. 1984. Cloning, mapping, and expression of genes involved in the fatty acid degradative multienzyme complex of Escherichia Coli. J. Bacteriol. 158:535-542. 